\title{
In vitro compatibility of remifentanil hydrochloride and sufentanil citrate with selected drugs
}

\author{
Valia Humbert-Delaloye, ${ }^{12}$ Markoulina Berger, ${ }^{1}$ Pierre Voirol, ${ }^{1}$ \\ André Pannatier ${ }^{12}$
}

\begin{abstract}
- An additional appendix is published online only. To view these files please visit the journal online (http://ejhp.bmj. com/content/19/1.toc
\end{abstract}

'Department of Pharmacy, University Hospital Centre (CHUV), Lausanne, Switzerland ${ }^{2}$ School of Pharmaceutical Sciences, University of Geneva and University of Lausanne, Geneva, Switzerland

\section{Correspondence to}

$\checkmark$ Humbert-Delaloye, Department of Pharmacy, Centre Hospitalier Universitaire Vaudois (CHUV), Rue du Bugnon 46, 1011 Lausanne, Switzerland;

valia.humbert-delaloye@ chuv.ch

\begin{abstract}
Objectives Physicochemical incompatibilities between intravenous drugs are a recurrent problem in intensive care units. The present study was aimed at investigating the physical compatibility of remifentanil and sufentanil with other drugs (insulin, midazolam, propofol, potassium chloride, magnesium sulfate, furosemide, heparin, monobasic potassium phosphate) that are frequently administered together intravenously. In addition, the physicochemical compatibility of three common associations of drugs was evaluated in glass tube tests and during dynamic simulated Y site administrations (remifentanil-insulinmidazolam; remifentanil-insulin-propofol; sufentanil-insulin-midazolam).
\end{abstract}

Methods Physical compatibility was verified by visual inspection of the various mixtures (two, three or four drugs) in glass tubes and by $\mathrm{pH}$ determination of the mixtures collected during simulated Y site administrations. Solutions were considered as compatible in the absence of any visual change in the solution and of any significant variation in $\mathrm{pH}$ value. In addition, chemical stability was checked during in vitro dynamic simulations. The solutions were prepared in $50 \mathrm{ml}$ syringes, placed on syringe pumps and connected to a Swan-Ganz catheter; the liquid collected at the tip was assayed by high performance liquid chromatography.

Results In the visual examinations, only the associations of remifentanil and furosemide were incompatible. The three assayed associations were compatible in the tested proportion range over $24 \mathrm{~h}$.

Conclusions Remifentanil was physically compatible with the tested drugs, except for furosemide (Lasix; Sanofi-Aventis, 250 mg/25 $\mathrm{ml}$ ) and physicochemically compatible with insulin and midazolam and insulin and propofol. Sufentanil was physically compatible with all tested drugs and physicochemically compatible with insulin and midazolam.

\section{INTRODUCTION}

Physicochemical incompatibilities between intravenous drugs pose a potential major problem in hospitals, mainly in intensive care units (ICU) where patients are administered several drugs simultaneously by the same intravenous line.

In the usual practice of our ICU, the nurses generally administer the drugs used for maintaining homeostasis as well as analgesic drugs in the same way. It is thus important that these drugs are compatible.
Remifentanil and sufentanil are analgesic drugs which are highly selective synthetic agonists of mu receptors. ${ }^{12}$ As they are relatively new drugs, data are still lacking about their compatibility with other drugs.

An observational study carried out in the 34 bed ICU of our university hospital and compiling all intravenous drugs received by the patients indicated that the most common associations involving remifentanil or sufentanil were ${ }^{3}$ : remifentanil-human insulinmidazolam; remifentanil-human insulin-propofol; sufentanil-human insulin-midazolam. Furthermore, remifentanil or sufentanil were also frequently administered together with potassium chloride (KCl), magnesium sulfate $\left(\mathrm{MgSO}_{4}\right)$, furosemide, heparin sodium or monobasic potassium phosphate $\left(\mathrm{KH}_{2} \mathrm{PO}_{4}\right)$.

Thus the aim of the present study was to evaluate the physical compatibility of remifentanil and sufentanil with one, two or three other drugs by visual inspection in test tubes. In addition, the chemical compatibility of the three drug associations was assessed by high performance liquid chromatography (HPLC) determinations and $\mathrm{pH}$ measurements during in vitro simulated $\mathrm{Y}$ site administrations.

\section{METHODS}

Solutions of drugs were prepared at the usual concentration and with the common diluents used in the adult ICU of our hospital:

- Remifentanil hydrochloride: Ultiva, GlaxoSmithKline (GlaxoSmithKline AG, Münchenbuchsee (CH)), $5 \mathrm{mg}$ and $1 \mathrm{mg}$ lyophilisate; $5+1 \mathrm{mg}$ in $50 \mathrm{ml}$ dextrose $5 \%(=0.12 \mathrm{mg} / \mathrm{ml}) ; \mathrm{pH}=3.3$

- Sufentanil citrate: Sufenta, Janssen-Cilag (JanssenCilag AG, Baar (CH)), 250 microgram $/ \mathrm{ml} / 5$ micro-

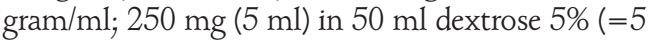
$\mathrm{mg} / \mathrm{ml}) ; \mathrm{pH}=4.2$

- Regular human insulin: Actrapid, Novo Nordisk (Novo Nordisk Pharma AG, Küsnacht/ZH (CH)), 1000 $\mathrm{U} / 10 \mathrm{ml} ; 50 \mathrm{U}(0.5 \mathrm{ml})$ in $50 \mathrm{ml}$ dextrose $5 \%$ (=1 $\mathrm{U} / \mathrm{ml}) ; \mathrm{pH}=4.3$

- Midazolam: Dormicum, Roche (Roche Pharma (Schweiz) AG, Reinach (CH)), 50 mg/10 ml; 50 $\mathrm{mg}(10 \mathrm{ml})$ in $50 \mathrm{ml}$ dextrose $5 \%(=1 \mathrm{mg} / \mathrm{ml})$; $\mathrm{pH}=3.4$

- Propofol: Disoprivan, AstraZeneca (AstraZeneca AG, Zug (CH)), $1000 \mathrm{mg} / 50 \mathrm{ml}$; undiluted (=20 $\mathrm{mg} / \mathrm{ml}) ; \mathrm{pH}=7.5$

- KCl: B Braun (B. Braun Medical AG, Sempach $(\mathrm{CH})), 50 \mathrm{mmol} / 50 \mathrm{ml}$; undiluted $(=1 \mathrm{mmol} / \mathrm{ml})$; $\mathrm{pH}=5.7$

- MgSO/GS: $\mathrm{MgSO}_{4}$, Bichsel (Laboratorium und Grosse Apotheke Dr. G. Bichsel AG, Interlaken $(\mathrm{CH})), 1000 \mathrm{mg} / 10 \mathrm{ml} ; 4000 \mathrm{mg}(40 \mathrm{ml})$ in 500 


\section{Table 1 Results of the visual compatibility tests between remifentanil hydrochloride and various drugs}

Remifentanil hydrochloride $0.12 \mathrm{mg} / \mathrm{ml}$ in D5W

\begin{tabular}{|c|c|c|c|c|}
\hline & Propofol $20 \mathrm{mg} / \mathrm{ml}$ & & & $\mathrm{C}$ \\
\hline & Midazolam $1 \mathrm{mg} / \mathrm{ml}$ in D5W & & & $C$ \\
\hline & Furosemide $1 \mathrm{mg} / \mathrm{ml}$ in $\mathrm{NS}$ & & & $\mathrm{IC}^{*}$ \\
\hline & Heparin sodium $416.7 \mathrm{U} / \mathrm{ml}$ in NS & & & $C$ \\
\hline & Monobasic potassium phosphate $1 \mathrm{mmol}$ & & & $\mathrm{C}$ \\
\hline & & - & & $C$ \\
\hline & Insulin $1 \mathrm{U} / \mathrm{ml}$ in $\mathrm{D} 5 \mathrm{~W}$ & Propofol $20 \mathrm{mg} / \mathrm{ml}$ & & $\mathrm{C}$ \\
\hline & & Midazolam $1 \mathrm{mg} / \mathrm{ml}$ in D5W & & $C$ \\
\hline & & - & & $C$ \\
\hline & & Insulin $1 \mathrm{U} / \mathrm{ml}$ in $\mathrm{D} 5 \mathrm{~W}$ & & $C$ \\
\hline & & Propofol $20 \mathrm{mg} / \mathrm{ml}$ & & $C$ \\
\hline & 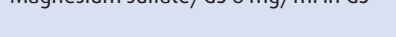 & Midazolam $1 \mathrm{mg} / \mathrm{ml}$ in D5W & & $\mathrm{C}$ \\
\hline & & Furosemide $1 \mathrm{mg} / \mathrm{ml}$ in NS & & $\mathrm{IC} \dagger$ \\
\hline & & Heparin sodium $416.7 \mathrm{U} / \mathrm{ml}$ in NS & & $C$ \\
\hline & & - & & $C$ \\
\hline & & Insulin $1 \mathrm{U} / \mathrm{ml}$ in $\mathrm{D} 5 \mathrm{~W}$ & & $C$ \\
\hline & Manoncium culfato $/ P 1 \mathrm{~s} 8 \mathrm{mo} / \mathrm{ml}$ in PIS & Propofol $20 \mathrm{mg} / \mathrm{ml}$ & & $C$ \\
\hline Remifentanil & 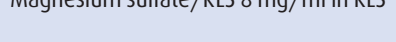 & Midazolam $1 \mathrm{mg} / \mathrm{ml}$ in D5W & & $\mathrm{C}$ \\
\hline hydrochloride & & Furosemide $1 \mathrm{mg} / \mathrm{ml}$ in NS & & $C$ \\
\hline $0.12 \mathrm{IIg} / \mathrm{MIIIII}$ USW & & Heparin sodium $416.7 \mathrm{U} / \mathrm{ml}$ in NS & & $C$ \\
\hline & & - & & $\mathrm{C}$ \\
\hline & & Insulin $1 \mathrm{U} / \mathrm{ml}$ in $\mathrm{D} 5 \mathrm{~W}$ & & $\mathrm{C}$ \\
\hline & & Propofol $20 \mathrm{mg} / \mathrm{ml}$ & & $C$ \\
\hline & & Midazolam $1 \mathrm{mg} / \mathrm{ml}$ in D5W & & $C$ \\
\hline & & Furosemide $1 \mathrm{mg} / \mathrm{ml}$ in NS & & $\mathrm{IC} \neq$ \\
\hline & & Heparin sodium $416.7 \mathrm{U} / \mathrm{ml}$ in NS & & $C$ \\
\hline & & & Insulin $1 \mathrm{U} / \mathrm{ml}$ in $\mathrm{D} 5 \mathrm{~W}$ & $\mathrm{C}$ \\
\hline & & & Propofol $20 \mathrm{mg} / \mathrm{ml}$ & $\mathrm{C}$ \\
\hline & Potassium chloride $1 \mathrm{mmol} / \mathrm{ml}$ & Magnesium sulfate $/ \mathrm{GS} 8 \mathrm{mg} / \mathrm{ml}$ in GS & Midazolam $1 \mathrm{mg} / \mathrm{ml}$ in D5W & $C$ \\
\hline & & & Furosemide $1 \mathrm{mg} / \mathrm{ml}$ in $\mathrm{NS}$ & $I C \S$ \\
\hline & & & Heparin sodium $416.7 \mathrm{U} / \mathrm{ml}$ in NS & $C$ \\
\hline & & & Insulin $1 \mathrm{U} / \mathrm{ml}$ in $\mathrm{D} 5 \mathrm{~W}$ & $C$ \\
\hline & & & Propofol $20 \mathrm{mg} / \mathrm{ml}$ & $C$ \\
\hline & & Mannesium sulfate / RI s $8 \mathrm{mo} / \mathrm{ml}$ in RIS & Midazolam $1 \mathrm{mg} / \mathrm{ml}$ in D5W & 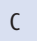 \\
\hline & & & Furosemide $1 \mathrm{mg} / \mathrm{ml}$ in NS & $\mathrm{C}$ \\
\hline & & & Heparin sodium $416.7 \mathrm{U} / \mathrm{ml}$ in NS & $C$ \\
\hline
\end{tabular}

"Remifentanil-furosemide: a white precipitate appeared in the 1:1 (with or without agitation), 1:4 and 4:1 solutions after 15,30 and 120 min, respectively.

†Remifentanil-MgS04/GS-furosemide: a white precipitate appeared in all solutions, after 15 min (1:1:1 and 4:1:4), 60 min (4:1:1), 24 h (1:1:4, 4:4:1) or more (1:4:1, 1:4:4). fRemifentanil-KCl-furosemide: a white precipitate appeared in the 4:1:4, 1:1:1, 4:1:1 and 4:4:1 solutions after 15, 60 , 120 min and 24 h respectively. The other solutions remained clear.

§Remifentanil-KCl-MgS04/GS-furosemide: a white precipitate appeared after 15 min (4:4:1:1, 4:1:1:4 solutions), 30 min (1:1:1:1, 4:1:1:1, 4:1:4:4, 4:4:1:4 solutions) and $24 \mathrm{~h}$ (4:1:4:1 solution). The other solutions remained clear, but the 1:1:4:4, 1:4:4:1 and 4:4:4:1 solutions showed a lot of little bubbles.

C, compatible; D5W, dextrose 5\%; GS, Glucosaline (3.3\% dextrose and 0.3\% NaCl); IC, incompatible; NS, NaCl 0.9\%; RLS, Ringer lactate stocker.

$\mathrm{ml}$ GlucoSaline (3.3\% dextrose and $0.3 \% \mathrm{NaCl})(=8 \mathrm{mg} / \mathrm{ml})$; $\mathrm{pH}=4.6$

- $\mathrm{MgSO}_{4} / \mathrm{RLS}: \mathrm{MgSO}_{4}$, Bichsel, $1000 \mathrm{mg} / 10 \mathrm{ml} ; 4000 \mathrm{mg}$ (40 ml) in $500 \mathrm{ml}$ Ringer lactate stocker* (=8 mg/ml); pH=6.1

- Furosemide: Lasix, Sanofi-Aventis (sanofi-aventis (schweiz) ag, Meyrin (CH)), $250 \mathrm{mg} / 25 \mathrm{ml} ; 50 \mathrm{mg}(5 \mathrm{ml}$ ) in $50 \mathrm{ml} \mathrm{NaCl} 0.9 \%$ (=1 mg/ml); $\mathrm{pH}=6.5$

- Heparin sodium: Liquémine, Drossapharm (Drossapharm AG, Basel (CH)), $25000 \mathrm{U} / 5 \mathrm{ml} ; 12500 \mathrm{U}(2.5 \mathrm{ml})$ in $30 \mathrm{ml} \mathrm{NaCl}$ $0.9 \%$ (=416.7 U/ml); $\mathrm{pH}=6.1$

- Monobasic potassium phosphate: $\mathrm{KH}_{2} \mathrm{PO}_{4}$, B Braun $10 \mathrm{mmol} / 10 \mathrm{ml}$; undiluted (=1 $\mathrm{mmol} / \mathrm{ml}) ; \mathrm{pH}=4.3$
- Maintenance infusion: GlucoSaline (GS), Ecoflac, B Braun 250 ml; $\mathrm{pH}=4.3$

- ${ }^{*}$ Ringer lactate stocker: infusion solution containing sodium 140 $\mathrm{mmol} / \mathrm{l}$, potassium $5.4 \mathrm{mmol} / \mathrm{l}$, calcium $1 \mathrm{mmol} / \mathrm{l}$, magnesium 1 $\mathrm{mmol} / \mathrm{l}$, lactate $27 \mathrm{mmol} / \mathrm{l}$, chlorure $122.4 \mathrm{mmol} / \mathrm{l}$.

\section{Assessment of physical compatibility in glass tubes}

Visual inspection of the various mixtures was performed in our quality control laboratory according to the European Pharmacopeia. ${ }^{4}$ Mixtures of two, three or four different drugs were tested in transparent colourless glass test tubes with a flat base and an internal diameter of $16 \mathrm{~mm}$. The tested associations are listed in table 1 


\section{Table 2 Results of the visual compatibility tests between sufentanil citrate and various drugs}

\begin{tabular}{|c|c|c|c|c|}
\hline & Propofol $20 \mathrm{mg} / \mathrm{ml}$ & & & $\mathrm{C}$ \\
\hline & Midazolam $1 \mathrm{mg} / \mathrm{ml}$ in $\mathrm{D} 5 \mathrm{~W}$ & & & $\mathrm{C}$ \\
\hline & Furosemide $1 \mathrm{mg} / \mathrm{ml}$ in $\mathrm{NS}$ & & & $\mathrm{C}$ \\
\hline & Heparin sodium $416.7 \mathrm{U} / \mathrm{ml}$ in NS & & & $\mathrm{C}$ \\
\hline & Monobasic potassium phosphate $1 \mathrm{mmol} / \mathrm{ml}$ & & & $\mathrm{C}$ \\
\hline & & - & & C \\
\hline & Insulin $1 \mathrm{U} / \mathrm{ml}$ in $\mathrm{D} 5 \%$ & Propofol $20 \mathrm{mg} / \mathrm{ml}$ & & $\mathrm{C}$ \\
\hline & & Midazolam $1 \mathrm{mg} / \mathrm{ml}$ in D5W & & $\mathrm{C}$ \\
\hline & & - & & $\mathrm{C}$ \\
\hline & & Insulin $1 \mathrm{U} / \mathrm{ml}$ in $\mathrm{D} 5 \mathrm{~W}$ & & $\mathrm{C}$ \\
\hline & Magnesium sulfate/GS 8 mg/ml in & Propofol $20 \mathrm{mg} / \mathrm{ml}$ & & $\mathrm{C}$ \\
\hline & GS & Midazolam $1 \mathrm{mg} / \mathrm{ml}$ in D5W & & $\mathrm{C}$ \\
\hline & & Furosemide $1 \mathrm{mg} / \mathrm{ml}$ in $\mathrm{NS}$ & & $\mathrm{C}$ \\
\hline & & Heparin sodium $416.7 \mathrm{U} / \mathrm{ml}$ in $\mathrm{NS}$ & & $\mathrm{C}$ \\
\hline & & - & & $\mathrm{C}$ \\
\hline & & Insulin $1 \mathrm{U} / \mathrm{ml}$ in $\mathrm{D} 5 \mathrm{~W}$ & & $\mathrm{C}$ \\
\hline & Magnesium sulfate/RLS $8 \mathrm{mg} / \mathrm{ml}$ in & Propofol $20 \mathrm{mg} / \mathrm{ml}$ & & $\mathrm{C}$ \\
\hline Sufentanil citrate & RLS & Midazolam $1 \mathrm{mg} / \mathrm{ml}$ in D5W & & $\mathrm{C}$ \\
\hline $\begin{array}{l}5 \text { microgram } / \mathrm{ml} \\
\text { in } \mathrm{D} 5 \mathrm{~W}\end{array}$ & & Furosemide $1 \mathrm{mg} / \mathrm{ml}$ in NS & & $\mathrm{C}$ \\
\hline & & Heparin sodium $416.7 \mathrm{U} / \mathrm{ml}$ in NS & & $\mathrm{C}$ \\
\hline & & - & & $\mathrm{C}$ \\
\hline & & Insulin $1 \mathrm{U} / \mathrm{ml}$ in $\mathrm{D} 5 \mathrm{~W}$ & & $\mathrm{C}$ \\
\hline & & Propofol $20 \mathrm{mg} / \mathrm{ml}$ & & $\mathrm{C}$ \\
\hline & & Midazolam $1 \mathrm{mg} / \mathrm{ml}$ in D5W & & $\mathrm{C}$ \\
\hline & & Furosemide $1 \mathrm{mg} / \mathrm{ml}$ in $\mathrm{NS}$ & & $\mathrm{C}$ \\
\hline & & Heparin sodium $416.7 \mathrm{U} / \mathrm{ml}$ in NS & & $\mathrm{C}$ \\
\hline & & & Insulin $1 \mathrm{U} / \mathrm{ml}$ in $\mathrm{D} 5 \mathrm{~W}$ & $\mathrm{C}$ \\
\hline & & & Propofol $20 \mathrm{mg} / \mathrm{ml}$ & $\mathrm{C}$ \\
\hline & Potassium chloride $1 \mathrm{mmol} / \mathrm{ml}$ & Magnesium sulfate $/ \mathrm{GS} 8 \mathrm{mg} / \mathrm{ml}$ in GS & Midazolam $1 \mathrm{mg} / \mathrm{ml}$ in D5W & $\mathrm{C}$ \\
\hline & & & Furosemide $1 \mathrm{mg} / \mathrm{ml}$ in $\mathrm{NS}$ & $\mathrm{C}$ \\
\hline & & & Heparin sodium $416.7 \mathrm{U} / \mathrm{ml}$ in NS & $\mathrm{C}$ \\
\hline & & & Insulin $1 \mathrm{U} / \mathrm{ml}$ in $\mathrm{D} 5 \mathrm{~W}$ & C \\
\hline & & & Propofol $20 \mathrm{mg} / \mathrm{ml}$ & C \\
\hline & & Magnesium sulfate/RLS $8 \mathrm{mg} / \mathrm{ml}$ in RLS & Midazolam $1 \mathrm{mg} / \mathrm{ml}$ in D5W & $\mathrm{C}$ \\
\hline & & & Furosemide $1 \mathrm{mg} / \mathrm{ml}$ in $\mathrm{NS}$ & $\mathrm{C}$ \\
\hline & & & Heparin sodium $416.7 \mathrm{U} / \mathrm{ml}$ in NS & $\mathrm{C}$ \\
\hline
\end{tabular}

C, compatible; D5W, dextrose 5\%; GS, Glucosaline (3.3\% dextrose and 0.3\% NaCl); NS, NaCl 0.9\%; RLS, Ringer lactate stocker.

(remifentanil hydrochloride) and table 2 (sufentanil citrate) (see results below).

For pairs of drugs, four tests were performed: $1+1 \mathrm{ml}$ without agitation, and $1+1,1+4$ and $4+1 \mathrm{ml}$ with agitation. Based on the same model, eight tests were performed for the combinations of three drugs, and 15 tests for the combinations of four drugs. Duplicate combinations were prepared, with permutation in the order of drug addition. A 1:1 ratio was chosen according to Allen et at while 1:4 ratios were used for simulating cases where one of the two drugs is administered faster than the other and will thus reach higher concentrations at the tubing Y site. The drugs were mixed with a Mini Vortexer VWR for $5 \mathrm{~s}$. In addition, a 1:1 ratio test was performed without mixing to better simulate a Y injection where mixing is not always immediate and homogenous.

Drugs were kept in tubes closed with screwed plastic caps and were maintained at room temperature (about $22^{\circ} \mathrm{C}$ ) for $24 \mathrm{~h}$ without light protection.
The solutions were examined for any visible change (haziness, precipitate, colour change, gas emission) after $0.1,0.25,0.5,1,2$, 4 and $24 \mathrm{~h}$. In accordance with the requirements of the European Pharmacopeia, ${ }^{4}$ the tubes were inspected macroscopically, first against a white background to look for appearance of any colour and then against a black background with polarised light to look for a precipitate, opacity or creaming of lipidic solutions. Drugs were considered compatible when no change was detected within $24 \mathrm{~h}$ in any of the various ratio mixtures.

Assessment of physicochemical compatibility in mixtures collected during in vitro simulated $\mathrm{Y}$ site administrations

A dynamic simulation of a Y site administration was realised, and the following associations were tested: remifentanil hydrochloride + human insulin + midazolam + maintenance infusion; remifentanil hydrochloride + human insulin + propofol + maintenance infusion; sufentanil citrate + human insulin + midazolam + maintenance infusion 


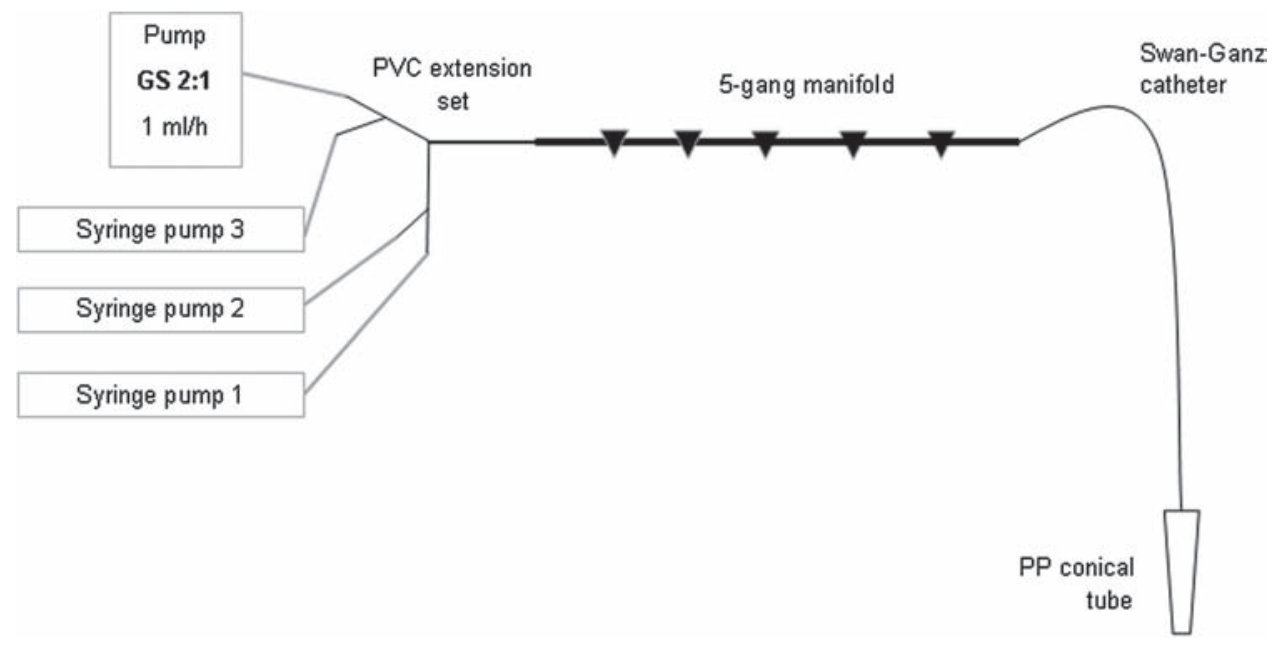

Figure 1 Schematic representation of the system used for performing in vitro simulated $\mathrm{Y}$ site administrations.

Each of these solutions was prepared in $50 \mathrm{ml}$ transparent BD Luer-Lok syringes with mounted needle (Becton Dickinson, article No 300136, Becton Dickinson AG, Allschwil (CH)), except for propofol which was supplied in $50 \mathrm{ml}$ ready to use glass syringes (Disoprivan PFS, AstraZeneca), and the maintenance infusion (GlucoSaline) which is available as a polyethylene low density infusion bag. The syringes were installed on syringe pumps (Pilot $\mathrm{C}$ or Orchestra Module DPS from Fresenius-Kabi, Fresenius Kabi (Schweiz) AG, Oberdorf $(\mathrm{CH})$ ) while the bags of maintenance infusion were connected to Volumed $\mu$ VP 5005 pumps from Arcomed, Fresenius Kabi (Schweiz) AG, Oberdorf (CH) or Orchestra Module MVP MS from Fresenius-Kabi. The Orchestra Module DPS and Orchestra Module MVP MS were connected to the Orchestra Base Intensive Workstation (Fresenius-Kabi).

All syringes were connected to $200 \mathrm{~cm}$ polyethylene syringe pump infusion lines (Fresenius-Kabi, article No 9004142) while the infusion bags were connected to $180 \mathrm{~cm} \mathrm{BD} \mathrm{R} 87 \mathrm{P}$ infusion sets (Becton Dickinson, article No 396350) or to $270 \mathrm{~cm} \mathrm{MS}$ 10 PVC infusion sets for Orchestra (Fresenius-Kabi, article No z072910F).

The three syringe pump infusion lines and the infusion set of the infusion bag were then connected to the four flexible lines of a $35 \mathrm{~cm}$ PVC extension set (LS-4 Connector, B Braun, article No 4097149, B.Braun Medical SA, Sempach (CH)). This extension set was itself connected to the end of a Discofix 5 gang manifold for infusion therapy (B Braun, article No 4085450, B.Braun Medical SA, Sempach $(\mathrm{CH})$ ), which was further connected to the proximal lumen of an Edwards Lifesciences heparin coated VIP Five Lumen Swan-Ganz Thermodilution Catheter (110 cm length, 7.5 F diameter; article No 831HF75, Edwards Lifesciences, Edwards Lifesciences SA, Nyon $(\mathrm{CH})$ ). The tip of this catheter was put in a $15 \mathrm{ml}$ polypropylene conical tube (BD Falcon, article No 352096, Becton Dickinson AG, Allschwil (CH)) where the mixtures were collected. The entire system is represented in figure 1.

The seven different rates of administration tested are shown in table 3 .

The $\mathrm{pH}$ and drug concentration in each syringe were measured before the beginning (T0) and after the end (T6 or T24) of each simulation. The syringes/bags were also weighed before and after the simulation. As the density of the various drugs was very close to 1.0 , the difference in weight allowed calculation of the exact administered volume. Thus, by knowing the duration of the simulation, it was then possible to calculate the administration rate to check if that was concordant with the rate chosen on the pumps.
$\mathrm{pH}$ was measured in $5 \mathrm{ml}$ of solution with a combined Metrosensor glass electrode Biotrode (article No 6.0224.100) connected to a Metrohm (Metrohm AG, Herisau (CH)) 713 pH meter.

A specific HPLC method was developed for each of the three tested associations (details of these methods are published in the supplement, available online only), allowing measurement of the concentration of each drug at the end of the Swan-Ganz catheter after 2, 4, 6 and $24 \mathrm{~h}$ for the 1:1:1 mixtures and after 2, 4 and $6 \mathrm{~h}$ for the other mixtures (when the flow of one of the drugs was $4 \mathrm{ml} / \mathrm{h}$, it was not possible to perform a study lasting $24 \mathrm{~h}$ as the $50 \mathrm{ml}$ syringe was empty too soon). The concentration after $1 \mathrm{~h}$ was also measured; however, as the system needed some time to equilibrate, the values obtained, if any, were not usable. The $\mathrm{pH}$ of the collected solution was also measured after 2, 4, 6 and $24 \mathrm{~h}$.

At the same time, the tested drugs were also mixed in glass test tubes and their concentrations measured immediately and after $24 \mathrm{~h}$ to obtain 'worst case' values that could be compared with the results of the dynamic simulation.

The drugs were considered as compatible if their respective concentrations remained between $90 \%$ and $110 \%$ of the expected value, ${ }^{6}$ and if the $\mathrm{pH}$ did not vary by more than 0.5 units between $\mathrm{T} 2$ and T6/24.

\section{RESULTS}

\section{Visual inspection}

The visual compatibility results for remifentanil and sufentanil with other drugs are described in tables 1 and 2, respectively. All visual incompatible associations involved remifentanil whereas sufentanil was compatible with all of the tested drugs.

\section{HPLC measures}

The measured concentrations of each drug in the various mixtures, either during dynamic simulations or in test tubes, are presented in tables 3-5. These are expressed as a percentage of the expected value, by knowing the flow rate of each drug of the tested association and its exact concentration in the syringe. No additional peaks of degradation products appeared on the chromatograms during the study.

Remifentanil hydrochloride, human insulin and midazolam No significant change in drug concentrations was noted between T0 and T6/T24 in the individual syringes for any of the tested drugs ( maximal variation for remifentanil $=1.0 \%$, for midazolam $=1.3 \%$ and for insulin=1.5\%), except for the insulin syringe in the 1:1:1 


\begin{tabular}{|c|c|c|c|c|c|c|c|c|}
\hline \multirow[b]{2}{*}{ Active drug } & \multicolumn{5}{|c|}{$\begin{array}{l}\% \text { of expected concentration } \\
\text { Dynamic simulation }\end{array}$} & \multicolumn{3}{|c|}{ Test tube } \\
\hline & Calculated flow rate & $2 \mathrm{~h}$ & $4 \mathrm{~h}$ & $6 \mathrm{~h}$ & $24 \mathrm{~h}$ & $\mathrm{Oh}$ & $24 \mathrm{~h}$ & Relative difference (\%) \\
\hline Remifentanil & $1 \mathrm{ml} / \mathrm{h}^{*}$ & 96.0 & 95.7 & 95.3 & 98.4 & 101.3 & 99.3 & -2.04 \\
\hline Midazolam & $1 \mathrm{ml} / \mathrm{h}^{*}$ & 109.8 & 102.0 & 94.1 & 91.2 & 104.8 & 105.3 & 0.48 \\
\hline Insulin & $1 \mathrm{ml} / \mathrm{h}^{*}$ & - & - & - & - & 107.0 & 105.1 & -1.77 \\
\hline Maintenance infusion & $1 \mathrm{ml} / \mathrm{h}^{*}$ & & & & & & & \\
\hline Remifentanil & $1 \mathrm{ml} / \mathrm{h}^{*}$ & 95.3 & 94.4 & 95.4 & & 91.8 & 90.3 & -1.65 \\
\hline Midazolam & $1 \mathrm{ml} / \mathrm{h}^{*}$ & 102.6 & 107.7 & 101.8 & & 94.3 & 94.7 & 0.42 \\
\hline Insulin & $4 \mathrm{ml} / \mathrm{h}^{*}$ & - & - & - & & 98.1 & 100.1 & 2.02 \\
\hline Maintenance infusion & $1 \mathrm{ml} / \mathrm{h}^{*}$ & & & & & & & \\
\hline Remifentanil & $1 \mathrm{ml} / \mathrm{h}^{*}$ & 98.0 & 100.8 & 102.8 & & 110.2 & 109.5 & -0.66 \\
\hline Midazolam & $4 \mathrm{ml} / \mathrm{h}^{*}$ & 104.5 & 100.5 & 97.6 & & 100.5 & 102.0 & 1.49 \\
\hline Insulin & $1 \mathrm{ml} / \mathrm{h} *$ & - & - & - & & 101.4 & 102.1 & 0.69 \\
\hline Maintenance infusion & $1 \mathrm{ml} / \mathrm{h}$ & & & & & & & \\
\hline Remifentanil & $1.06 \mathrm{ml} / \mathrm{h}$ & 100.3 & 103.3 & 103.9 & & 94.2 & 95.0 & 0.85 \\
\hline Midazolam & $4.16 \mathrm{ml} / \mathrm{h}$ & 105.7 & 102.4 & 102.2 & & 97.0 & 96.9 & -0.10 \\
\hline Insulin & $4.20 \mathrm{ml} / \mathrm{h}$ & - & - & - & & 104.8 & 103.9 & -0.86 \\
\hline Maintenance infusion & $1.00 \mathrm{ml} / \mathrm{h}$ & & & & & & & \\
\hline Remifentanil & $4.28 \mathrm{ml} / \mathrm{h}$ & 107.1 & 106.8 & 105.5 & & 108.3 & 109.0 & 0.64 \\
\hline Midazolam & $1.15 \mathrm{ml} / \mathrm{h}$ & 109.7 & 108.1 & 108.9 & & 101.2 & 100.3 & -0.89 \\
\hline Insulin & $1.14 \mathrm{ml} / \mathrm{h}$ & - & - & - & & 102.3 & 101.5 & -0.79 \\
\hline Maintenance infusion & $1.26 \mathrm{ml} / \mathrm{h}$ & & & & & & & \\
\hline Remifentanil & $3.86 \mathrm{ml} / \mathrm{h}$ & 99.4 & 100.9 & 102.7 & & 97.6 & 97.9 & 0.31 \\
\hline Midazolam & $1.08 \mathrm{ml} / \mathrm{h}$ & 108.8 & 106.7 & 106.7 & & 93.5 & 92.5 & -1.08 \\
\hline Insulin & $4.27 \mathrm{ml} / \mathrm{h}$ & - & - & - & & 104.2 & 103.3 & -0.87 \\
\hline Maintenance infusion & $1.19 \mathrm{ml} / \mathrm{h}$ & & & & & & & \\
\hline Remifentanil & $4.14 \mathrm{ml} / \mathrm{h}$ & 104.8 & 105.2 & 105.9 & & 98.2 & 97.8 & -0.40 \\
\hline Midazolam & $4.09 \mathrm{ml} / \mathrm{h}$ & 105.6 & 105.8 & 103.2 & & 91.3 & 90.4 & -0.98 \\
\hline Insulin & $1.08 \mathrm{ml} / \mathrm{h}$ & - & - & - & & 104.2 & 105.2 & 0.96 \\
\hline Maintenance infusion & $1.12 \mathrm{ml} / \mathrm{h}$ & & & & & & & \\
\hline
\end{tabular}

"The syringe not having been weighed, the flow rate could not be calculated.

test which stayed on the syringe pump for $24 \mathrm{~h}$ and showed a concentration variation of 9.7\%. In addition, $\mathrm{pH}$ values were also stable (change $\leq 0.17 \mathrm{pH}$ units in each syringe of the three drugs in all tests).

The measured concentrations of each drug in the remifentanilinsulin-midazolam mixture are presented in table 3. Remifentanil and midazolam concentrations in the various tests did not show any decrease between T0 and T6/T24. For technical reasons, the concentration of insulin could not be determined during the dynamic tests; however, this concentration stayed stable in the test tubes for $24 \mathrm{~h}$.

Remifentanil hydrochloride, human insulin and propofol No significant change in drug concentrations was noted between T0 and T6/T24 in the individual syringes for any of the tested drugs (maximal variation for remifentanil $=0.8 \%$, for propofol $=1.5 \%$ and for insulin $=1.9 \%$ ). In addition, $\mathrm{pH}$ values were also stable (change $\leq 0.10 \mathrm{pH}$ units for the propofol and insulin syringes and $\leq 0.50 \mathrm{pH}$ units for the remifentanil syringes, in all tests).
The assay results obtained with the remifentanil-insulin-propofol mixture are shown in table 4. Remifentanil and insulin concentrations in the various tests remained stable or showed only a slight decrease. The decrease in propofol was more marked, with variations ranging from $3 \%$ until almost 10\% loss after $24 \mathrm{~h}$.

Sufentanil citrate, human insulin and midazolam

No significant change in drug concentrations was noted between T0 and T6/T24 in the individual syringes for any of the tested drugs ( maximal variation for sufentanil $=1.7 \%$, for midazolam $=1.9 \%$ and for insulin=2.1\%), except for the insulin syringe in the 1:1:1 test which stayed on the syringe pump for $24 \mathrm{~h}$ and showed a concentration variation of $8.3 \%$. In addition, $\mathrm{pH}$ values were also stable (change $\leq 0.18 \mathrm{pH}$ units in each syringe of the three drugs in all tests).

The results of the drug concentration measurements in the sufentanil-midazolam-insulin association are shown in table 5 . With the exception of a very low concentration of midazolam at T2 for the 1:1:1 and 1:1:4 mixtures, the concentration of these 
Table 4 Results of the high performance liquid chromatography determinations of drug concentrations in the remifentanil-human insulinpropofol combination. Considering the extensive handling required for assaying these three drugs, they were measured only at T0 and T24 in test tubes and not with dynamic simulation

\begin{tabular}{|c|c|c|c|c|}
\hline \multirow[b]{2}{*}{ Active drug } & \multirow[b]{2}{*}{ Simulated flow rate } & \multicolumn{2}{|c|}{$\%$ of expected concentration in test tube } & \multirow[b]{2}{*}{ Relative difference (\%) } \\
\hline & & $\mathrm{Oh}$ & $24 \mathrm{~h}$ & \\
\hline Remifentanil & $1 \mathrm{ml} / \mathrm{h}$ & 107.1 & 104.0 & -2.97 \\
\hline Insulin & $1 \mathrm{ml} / \mathrm{h}$ & 105.9 & 105.9 & 0.00 \\
\hline Maintenance infusion & $1 \mathrm{ml} / \mathrm{h}$ & & & \\
\hline Propofol & $1 \mathrm{ml} / \mathrm{h}$ & 103.4 & 100.5 & -2.84 \\
\hline Insulin & $4 \mathrm{ml} / \mathrm{h}$ & 102.4 & 105.0 & 2.47 \\
\hline Maintenance infusion & $1 \mathrm{ml} / \mathrm{h}$ & & & \\
\hline Maintenance infusion & $1 \mathrm{ml} / \mathrm{h}$ & & & \\
\hline Remifentanil & $1 \mathrm{ml} / \mathrm{h}$ & 96.3 & 96.8 & 0.49 \\
\hline Propofol & $4 \mathrm{ml} / \mathrm{h}$ & 99.5 & 94.2 & -5.45 \\
\hline Insulin & $4 \mathrm{ml} / \mathrm{h}$ & 98.9 & 97.2 & -1.69 \\
\hline Maintenance infusion & $1 \mathrm{ml} / \mathrm{h}$ & & & \\
\hline Remifentanil & $4 \mathrm{ml} / \mathrm{h}$ & 100.7 & 97.5 & -3.18 \\
\hline Insulin & $4 \mathrm{ml} / \mathrm{h}$ & 100.0 & 95.1 & -5.01 \\
\hline Maintenance infusion & $1 \mathrm{ml} / \mathrm{h}$ & & & \\
\hline Remifentanil & $4 \mathrm{ml} / \mathrm{h}$ & 103.7 & 105.4 & 1.61 \\
\hline Propofol & $4 \mathrm{ml} / \mathrm{h}$ & 102.6 & 93.4 & -9.43 \\
\hline Insulin & $1 \mathrm{ml} / \mathrm{h}$ & 91.6 & 93.0 & 1.58 \\
\hline Maintenance infusion & $1 \mathrm{ml} / \mathrm{h}$ & & & \\
\hline
\end{tabular}

three drugs in the various tests did not show any decrease between T0 and T6/T24.

\section{DISCUSSION}

Visual examination

Remifentanil hydrochloride $120 \mu \mathrm{g} / \mathrm{ml}$ was incompatible only with furosemide, individually or in association with one or two other drugs $\left(\mathrm{KCl}\right.$ and/or $\mathrm{MgSO}_{4}$ ). The only exception was the association of remifentanil hydrochloride with furosemide, and $\mathrm{MgSO} 4 / \mathrm{RLS}$, which remained clear, in contrast with the association of remifentanil, furosemide and $\mathrm{MgSO}_{4} / \mathrm{GS}$, which precipitated. With the exception of furosemide, remifentanil was compatible with all of the other tested drugs. Trissel et al demonstrated visual compatibility of remifentanil 25 or $250 \mu \mathrm{g} /$ $\mathrm{ml}$ with midazolam $1 \mathrm{mg} / \mathrm{ml}$, heparin sodium $100 \mathrm{U} / \mathrm{ml}$, magnesium sulfate $100 \mathrm{mg} / \mathrm{ml}, \mathrm{KCl} 0.1 \mathrm{mmol} / \mathrm{ml}$ and furosemide $3 \mathrm{mg} / \mathrm{ml} .^{8}$ These results are concordant with our results, except for furosemide. The difference can be explained by a difference in the composition of the drug solution. Indeed, the furosemide tested here (Lasix, Sanofi-Aventis $250 \mathrm{mg} / 25 \mathrm{ml}$ ) contained mannitol as an excipient, which was not present in the furosemide solution tested by Trissel et al. We repeated the same test with another furosemide formulation available on the Swiss market (Lasix, Sanofi-Aventis, $20 \mathrm{mg} / 2 \mathrm{ml}$ ) for which the only excipient 


\begin{tabular}{|c|c|c|c|c|c|c|c|c|}
\hline \multirow{2}{*}{ Active drug } & \multicolumn{8}{|c|}{$\%$ of expected concentration } \\
\hline & \multicolumn{5}{|l|}{ Dynamic simulation } & \multicolumn{3}{|l|}{ Test tube } \\
\hline Sufentanil & $1.06 \mathrm{ml} / \mathrm{h}$ & 98.8 & 106.0 & 107.0 & 101.4 & 103.4 & 103.3 & -0.06 \\
\hline Midazolam & $1.02 \mathrm{ml} / \mathrm{h}$ & 33.4 & 99.0 & 99.0 & 98.9 & 107.8 & 108.7 & 0.80 \\
\hline Maintenance infusion & $1.07 \mathrm{ml} / \mathrm{h}$ & & & & & & & \\
\hline Sufentanil & $1.07 \mathrm{ml} / \mathrm{h}$ & 106.1 & 102.6 & 106.8 & & 100.2 & 100.3 & 0.10 \\
\hline Midazolam & $1.02 \mathrm{ml} / \mathrm{h}$ & 74.1 & 96.4 & 97.8 & & 95.6 & 94.3 & -1.37 \\
\hline Insulin & $4.15 \mathrm{ml} / \mathrm{h}$ & 106.9 & 106.8 & 106.8 & & 99.5 & 99.2 & -0.30 \\
\hline Insulin & $1.00 \mathrm{ml} / \mathrm{h}$ & - & - & - & & 103.5 & 105.7 & 2.10 \\
\hline Maintenance infusion & $1.07 \mathrm{ml} / \mathrm{h}$ & & & & & & & \\
\hline Sufentanil & $1.05 \mathrm{ml} / \mathrm{h}$ & - & - & - & & 108.1 & 107.9 & -0.19 \\
\hline Midazolam & $4.13 \mathrm{ml} / \mathrm{h}$ & 98.5 & 100.2 & 99.9 & & 92.8 & 94.2 & 1.54 \\
\hline Insulin & $4.17 \mathrm{ml} / \mathrm{h}$ & - & - & - & & 97.8 & 98.1 & 0.31 \\
\hline Maintenance infusion & $1.08 \mathrm{ml} / \mathrm{h}$ & & & & & & & \\
\hline Sufentanil & $4.15 \mathrm{ml} / \mathrm{h}$ & 106.9 & 101.6 & 108.2 & & 107.0 & 107.6 & 0.56 \\
\hline Midazolam & $1.03 \mathrm{ml} / \mathrm{h}$ & 100.9 & 99.4 & 103.9 & & 99.4 & 100.6 & 1.20 \\
\hline Insulin & $0.99 \mathrm{ml} / \mathrm{h}$ & - & - & - & & 99.8 & 99.0 & -0.80 \\
\hline Midazolam & $4.11 \mathrm{ml} / \mathrm{h}$ & 105.8 & 104.5 & 104.5 & & 97.4 & 98.4 & 1.08 \\
\hline Insulin & $1.12 \mathrm{ml} / \mathrm{h}$ & - & - & - & & 103.3 & 101.7 & -1.56 \\
\hline Maintenance infusion & $1.00 \mathrm{ml} / \mathrm{h}$ & & & & & & & \\
\hline
\end{tabular}

is $\mathrm{NaCl}$. The final mixture $(1 \mathrm{mg} / \mathrm{ml}$ in $\mathrm{NaCl} 0.9 \%)$ had a $\mathrm{pH}$ of 8.2 (instead of 6.5 with Lasix $250 \mathrm{mg} / 25 \mathrm{ml}$ ) and the precipitate did not appear. The reaction variability of both Lasix solutions in the presence of remifentanil could be due to a $\mathrm{pH}$ variation of the final solutions obtained after mixing remifentanil and furosemide. The fact that the precipitate appeared when mixed with $\mathrm{MgSO}_{4} / \mathrm{GS}(\mathrm{pH}=4.6)$, but not with $\mathrm{MgSO}_{4} / \mathrm{RLS}(\mathrm{pH}=6.1)$, corroborates this finding.

The visual tests indicated total compatibility of sufentanil citrate $5 \mu \mathrm{g} / \mathrm{ml}$ with all of the tested drugs, in combinations associating two, three or four drugs. Trissel et al demonstrated compatibility of sufentanil $12.5 \mu \mathrm{g} / \mathrm{ml}$ with propofol $10 \mathrm{mg} / \mathrm{ml}$ for $1 \mathrm{~h},{ }^{9}$ and with midazolam $0.2 \mathrm{mg} / \mathrm{ml}$ for $24 \mathrm{~h} .{ }^{10}$ The results obtained here corroborate these compatibilities, but at different concentrations, and with more combinations, including associations of 3-4 drugs.

\section{HPLC measures}

Remifentanil hydrochloride, human insulin and midazolam

HPLC determinations carried out with the combination of remifentanil, insulin and midazolam showed complete physicochemical compatibility over $24 \mathrm{~h}$ by $\mathrm{Y}$ site administration, regardless of the relative administration rate of each drug. But the content of the insulin syringe after $24 \mathrm{~h}$ was hardly in the expected range $( \pm 10 \%)$. This loss could be due to degradation of the drug but, because no degradation peak was visible, it could also be explained by insulin adsorption to the surfaces of the infusion containers and/or tubing, a well recognised phenomenon. ${ }^{10}$ Whatever the cause, the insulin syringes should not be kept for longer than $24 \mathrm{~h}$.

The compatibility of midazolam $(1 \mathrm{mg} / \mathrm{ml})$ and remifentanil (25 and $250 \mu \mathrm{g} / \mathrm{ml}$ ) has already been proven by Trissel et a ${ }^{\beta}$ over $4 \mathrm{~h}$. Yamashita et al proved that midazolam $1 \mathrm{mg} / \mathrm{ml}$ was visually compatible with regular insulin $1 \mathrm{U} / \mathrm{ml}$ over 24 h. ${ }^{7}$ However, no study has assessed the compatibility of remifentanil and insulin or the compatibility of the three drugs together. The results obtained in this study complete these data.

Remifentanil hydrochloride, human insulin and propofol

HPLC determinations carried out with remifentanil, insulin and propofol showed complete compatibility over $24 \mathrm{~h}$ by $\mathrm{Y}$ site administration at any tested proportion. However, the propofol 
concentration showed a decrease and did not remain in the expected range after $24 \mathrm{~h}$. This is not a significant problem for usual ICU practice as in Switzerland the manufacturer of Disoprivan recommends changing the syringes every $8 \mathrm{~h}$ to avoid microbiological contamination. ${ }^{2}$

The results of this study should increase the available information about the compatibilities of these three drugs, as only the compatibility of propofol $10 \mathrm{mg} / \mathrm{ml}$ with regular insulin $1 \mathrm{U} / \mathrm{ml}$ had been proven over $1 \mathrm{~h} .^{9}$

In our study, evaluation of the compatibility of propofol with insulin and remifentanil was based only on HPLC assay. However, some authors recommend considering the size variation of the droplets as well as evaluating whether or not this drug is compatible with others. ${ }^{11}$ If there is a considerable increase in droplet size it could be dangerous for the patient, thereby leading to a risk of pulmonary embolism. As the instrumentation required was not available, droplet size could not be measured which could be a limitation of this work.

Sufentanil citrate, human insulin and midazolam

HPLC determinations conducted on a combination of sufentanil, insulin and midazolam showed complete compatibility over $24 \mathrm{~h}$ by $\mathrm{Y}$ site administration at any tested proportion. In the literature, only the compatibility of sufentanil citrate $12.5 \mu \mathrm{g} / \mathrm{ml}$ with midazolam $0.2 \mathrm{mg} / \mathrm{ml}$ for $24 \mathrm{~h}$ was reported previously. ${ }^{10}$ These data extend the information on the compatibility of sufentanil citrate.

Unfortunately, the low concentration of midazolam at T2 in the 1:1:1 and 1:1:4 associations (dynamic simulation) could not be explained.

\section{CONCLUSION}

Visual examination revealed that remifentanil showed incompatibility only with furosemide (Lasix, Sanofi-Aventis, $250 \mathrm{mg} / 25 \mathrm{ml}$ ) whereas sufentanil was compatible with all the tested drugs, even in combination with three or four drugs.

The three assayed associations were found to be compatible; however, the concentration of propofol tends to lower over time, as is barely within the accepted range after $24 \mathrm{~h}$.

Acknowledgements The authors thank Bernard Testa, Emeritus Professor, for his linguistic help.

\section{Key messages}

Remifentanil is physically compatible with insulin, midazolam, propofol, potassium chloride, magnesium sulfate, heparin and monobasic potassium phosphate, and physicochemically compatible with insulin and midazolam or insulin and propofol. It is not compatible with furosemide (Lasix, SanofiAventis, $250 \mathrm{mg} / 25 \mathrm{ml}$ ). Sufentanil is physically compatible with insulin, midazolam, propofol, potassium chloride, magnesium sulfate, furosemide, heparin and monobasic potassium phosphate, and physicochemically compatible with insulin and midazolam

Contributors This paper was reviewed and approved by all named authors, and each contributed significantly to the publication.

Competing interests None.

Provenance and peer review Not commissioned; externally peer reviewed. Received 1 December 2011

Accepted 11 January 2012

\section{References}

1. Micromedex 1.0 (Healthcare series) (online version). Greenwood Village, CO: Thomson Reuters (Healthcare), 2011.

2. Swiss compendium of drugs, 32nd Edn. Basel: Documed SA, 2011.

3. Delaloye Valia, Pannatier André. Administration des médicaments par voie parentérale aux soins intensifs, évaluation et validation des pratiques infirmières. Personal dissertation. Geneva: Sciences Faculty of Geneva University, 2006.

4. Clarity and degree of opalescence of liquids, visual method (2.2.1); Degree of colouration of liquids (2.2.2). In: European pharmacopeia, 7th Edn. Strasbourg: European Directorate for the Quality of Medicines and HealthCare (edqm), 2011:21-24.

5. Allen LV Jr, Levinson RS, Phisutsinthop D. Compatibility of various admixtures with secondary additives at Y-injection sites of intravenous administration sets. Am J Hosp Pharm 1977;34:939-43.

6. General clauses (17.1). In: Swissmedic, Swiss Agency for Therapeutic Products. Swiss Pharmacopeia, Ph.Helv.10. Bern: BBL, 2006:113.

7. Yamashita SK, Walker SE, Choudhury T, et al. Compatibility of selected critical care drugs during simulated Y-site administration. Am J Health Syst Pharm 1996;53:1048-51.

8. Trissel LA, Gilbert DL, Martinez JF, et al. Compatibility of remifentanil hydrochloride with selected drugs during simulated Y-site administration. Am J Health Syst Pharm 1997;54:2192-6.

9. Trissel LA, Gilbert DL, Martinez JF. Compatibility of propofol injectable emulsion with selected drugs during simulated Y-site administration. Am J Health Syst Pharm 1997:54:1287-92.

10. Trissel LA. Handbook on injectable drugs, 16th Edn. Bethesda, MD: ASHP, 2011.

11. Chernin EL, Smiler B. Any propofol compatibility study must include an emulsion stability analysis. Anesth Analg 2000;91:1307-8. 